Key Words:

Saltstone

TCLP

Benzene

Tetraphenylborate

Tank $48 H$

Retention: Permanent

\title{
TOXICITY CHARACTERISTIC LEACHING PROCEDURE APPLIED TO RADIOACTIVE SALTSTONE CONTAINING TETRAPHENYLBORATE: DEVELOPMENT OF A MODIFIED ZERO-HEADSPACE EXTRACTOR
}

K. P. Crapse, A. D. Cozzi, C. L. Crawford, A. R. Jurgensen

With contributions by J. R. Zamecnik, C. A. Langton, D. M. Missimer

September 2006
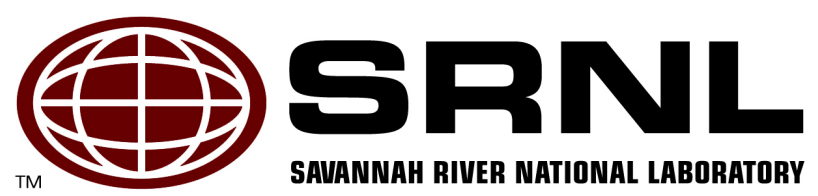
WSRC-STI-2006-00028

Revision 0

\section{DISCLAIMER}

This report was prepared by Westinghouse Savannah River Company (WSRC) for the United States Department of Energy under Contract No. DE-AC09-96SR18500 and is an account of work performed under that contract. Neither the United States Department of Energy, nor WSRC, nor any of their employees makes any warranty, expressed or implied, or assumes any legal liability or responsibility for the accuracy, completeness, or usefulness, of any information, apparatus, or product or process disclosed herein or represents that its use will not infringe privately owned rights. Reference herein to any specific commercial product, process, or service by trademark, name, manufacturer or otherwise does not necessarily constitute or imply endorsement, recommendation, or favoring of same by WSRC or by the United States Government or any agency thereof. The views and opinions of the authors expressed herein do not necessarily state or reflect those of the United States Government or any agency thereof.

\section{Printed in the United States of America}

Prepared For

U.S. Department of Energy 
Key Words:

Saltstone

TCLP

Benzene

Tetraphenylborate

Tank $48 \mathrm{H}$

Retention: Permanent

\section{TOXICITY CHARACTERISTIC LEACHING PROCEDURE APPLIED TO RADIOACTIVE SALTSTONE CONTAINING TETRAPHENYLBORATE: DEVELOPMENT OF A MODIFIED ZERO-HEADSPACE EXTRACTOR}

K. P. Crapse, A. D. Cozzi, C. L. Crawford, A. R. Jurgensen

With contributions by J. R. Zamecnik, C. A. Langton, D. M. Missimer

September 2006

Immobilization Technology Section Savannah River National Laboratory Aiken, SC 29808

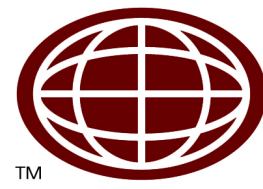




\section{REVIEWS AND APPROVALS}

\section{AUTHORS:}

$\overline{\text { A. D. Cozzi, Process Science \& Engineering }}$ Date

$\overline{\text { K. P. Crapse, Chemical Science \& Technology }}$ Date

$\begin{array}{ll}\text { C. L. Crawford, Process Science \& Engineering } & \text { Date }\end{array}$

$\overline{\text { A. R. Jurgensen, Analytical Development }}$ Date

\section{TECHNICAL REVIEWER:}

N. E. Bibler, Process Science \& Engineering

Date

M. R. Poirier, Chemical Science \& Technology

Date

\section{APPROVERS:}

R. E. Edwards, Manager, Process Science \& Engineering Date

D. A. Crowley, Manager, Stabilization Science Research $\quad$ Date

$\overline{\text { J. E. Occhipinti, Manager, Waste Solidification Engineering }}$ Date 


\section{EXECUTIVE SUMMARY}

In order to assess the effect of extended curing times at elevated temperatures on saltstone containing Tank $48 \mathrm{H}$ waste, saltstone samples prepared as a part of a separate study ${ }^{1}$ were analyzed for benzene using a modification of the United States Environmental Protection Agency (USEPA) method 1311 Toxicity Characteristic Leaching Procedure (TCLP). To carry out TCLP for volatile organic analytes (VOA), such as benzene, in the Savannah River National Laboratory (SRNL) shielded cells (SC), a modified TCLP Zero-Headspace Extractor (ZHE) was developed. The modified method was demonstrated to be acceptable in a side by side comparison with an EPA recommended ZHE using nonradioactive saltstone containing tetraphenylborate (TPB). TCLP results for all saltstone samples tested containing TPB (both simulant and actual Tank $48 \mathrm{H}$ waste) were below the regulatory limit for benzene $(0.5 \mathrm{mg} / \mathrm{L})$. In general, higher curing temperatures corresponded to higher concentrations of benzene in TCLP extract. The TCLP performed on the simulant samples cured under the most extreme conditions (3000 mg/L TPB in salt and cured at $95{ }^{\circ} \mathrm{C}$ for at least 144 days) resulted in benzene values that were greater than half the regulatory limit. Taking into account that benzene in TCLP extract was measured on the same order of magnitude as the regulatory limit, that these experimental conditions may not be representative of actual curing profiles found in the saltstone vault and that there is significant uncertainty associated with the precision of the method, it is recommended that to increase confidence in TCLP results for benzene, the maximum curing temperature of saltstone be less than $95^{\circ} \mathrm{C}$. At this time, no further benzene TCLP testing is warranted. Additional verification would be recommended, however, should future processing strategies result in significant changes to salt waste composition in saltstone as factors beyond the scope of this limited study may influence the decomposition of TPB in saltstone.

\footnotetext{
${ }^{1}$ Cozzi, A. D., Eibling, R. A, Marinik, A. R., and Zamecnik, J. R. Tetraphenylborate Decomposition in Saltstone-
} Final Report, Technical Report WSRC-STI-2006-00026, Savannah River Site, Aiken, SC 29803, 2006. 


\section{TABLE OF CONTENTS}

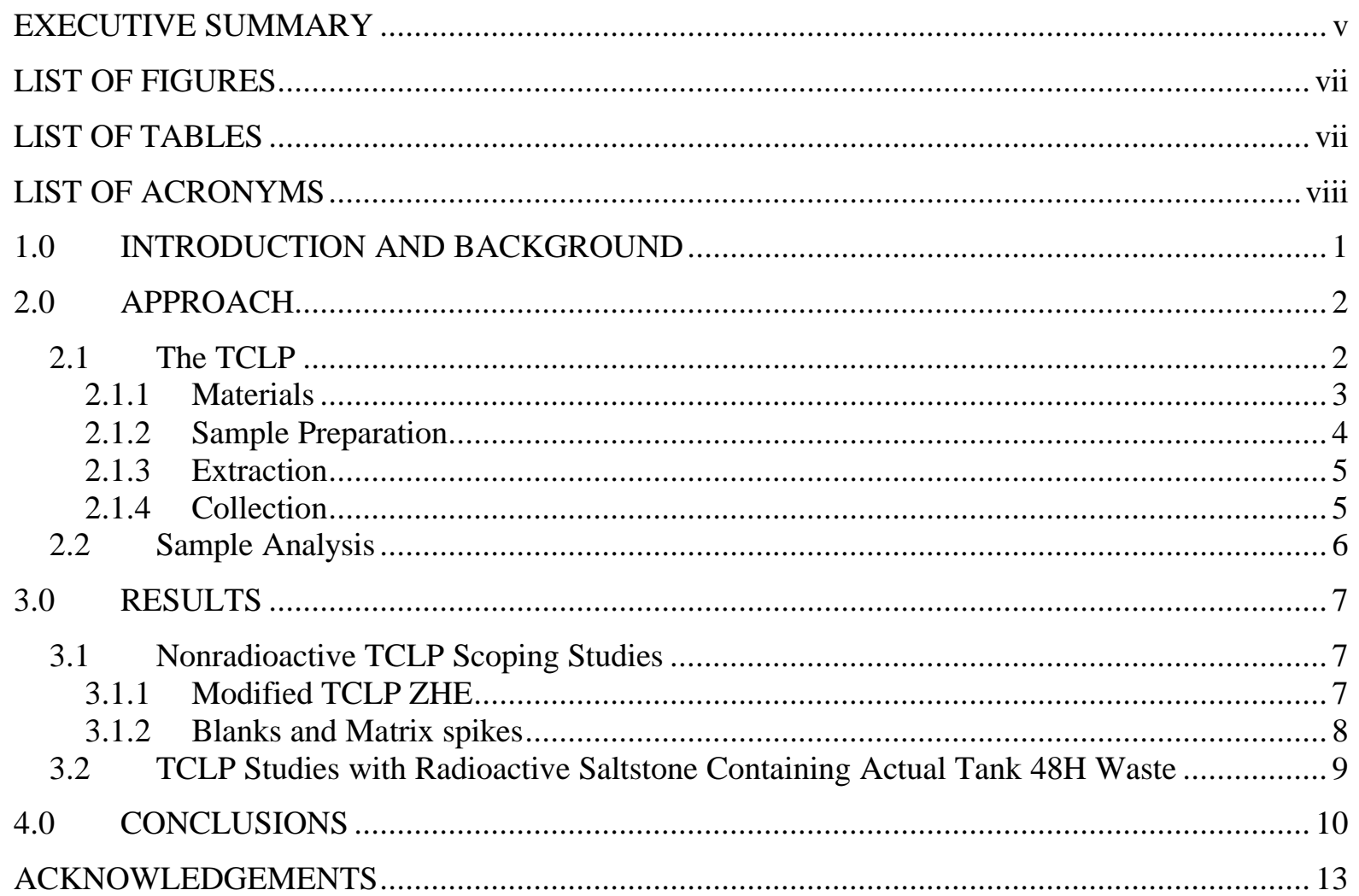


WSRC-STI-2006-00028

Revision 0

\section{LIST OF FIGURES}

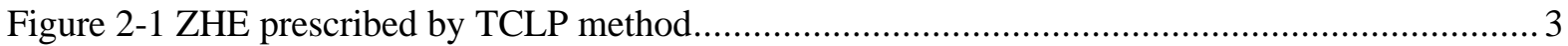

Figure 2-2 Rotator used for TCLP in SRNL shielded cells ........................................................ 4

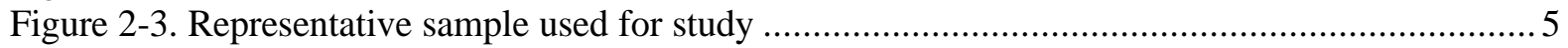

Figure 2-4 Sectioning strategy for saltstone samples .......................................................... 5

Figure 2-5 Collection of extract from gas-tight syringe ZHE .................................................... 6

\section{LIST OF TABLES}

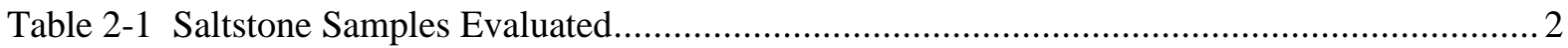

Table 3-1 Benzene TCLP Results for Nonradioactive Saltstone Samples .................................... 8

Table 3-2 Benzene TCLP Results for Radioactive Saltstone Samples Containing Tank 48H Waste.... 9 
WSRC-STI-2006-00028

Revision 0

\section{LIST OF ACRONYMS}

\begin{tabular}{|l|l|}
\hline AD & SRNL Analytical Development \\
\hline DWPF & Defense Waste Processing Facility \\
\hline EPA & Environmental Protection Agency \\
\hline GC & Gas Chromatography \\
\hline KTPB & Potassium tetraphenylborate \\
\hline MS & Mass Spectrometry \\
\hline RSD & Relative Standard Deviation \\
\hline SCDHEC & South Carolina Department of Health and Environmental Control \\
\hline SCO & Shielded Cells Operations \\
\hline SDF & Saltstone Disposal Facility \\
\hline SPF & Saltstone Processing Facility \\
\hline SRNL & Savannah River National Laboratory \\
\hline TCLP & Toxic Characteristic Leaching Procedure \\
\hline TPB & Tetraphenylborate \\
\hline US & United States \\
\hline VOA & volatile organic analytes \\
\hline ZHE & zero-headspace extractor \\
\hline
\end{tabular}




\subsection{INTRODUCTION AND BACKGROUND}

The Z-Area Saltstone Disposal Facility (SDF) is permitted by the South Carolina Department of Health and Environmental Control (SCDHEC) as an industrial solid waste landfill. ${ }^{*}$ The permit requires periodic testing to verify the nonhazardous (as defined by the United States Environmental Protection Agency $\left.(E P A)^{2}\right)$ nature of the saltstone placed in the SDF. The characteristic hazard of toxicity ${ }^{\dagger}$ is the only hazard that applies to the SDF. The test to determine if saltstone is hazardous for toxicity is an EPA leaching procedure SW-846 Method 1311, the Toxicity Characteristic Leaching Procedure (TCLP). ${ }^{3}$

Currently, the aggregation of Tank $48 \mathrm{H}$ waste for processing through the Saltstone Processing Facility (SPF) for placement in the SDF is being maintained as an alternative strategy for Tank $48 \mathrm{H}$ waste disposition. ${ }^{4}$ This strategy resulted in a review of documentation for the production of benzene via the decomposition of potassium tetraphenylborate (KTPB) solids at elevated temperatures for an extended period of time. The effect of TPB and TPB decomposition products on saltstone has been addressed previously $^{5,6}$ The current operating strategy for processing saltstone is projected to result in elevated temperatures in the saltstone vaults. ${ }^{7}$ The saltstone is expected to be at these elevated temperatures for a period of months. An evaluation of prior saltstone vault temperatures confirmed that previous facility operation has not resulted in elevated temperatures for extended periods of time. ${ }^{7}$ There is a concern that the saltstone prepared with Tank $48 \mathrm{H}$ waste that passed the TCLP after a 28 day curing period, ${ }^{8,9}$ may become a hazardous material for benzene at a later date due to extended times at these higher curing temperatures. Although the previous upper operating limit for the temperature of saltstone was $95{ }^{\circ} \mathrm{C},{ }^{10}$ the current Technical Safety Requirements for the SDF limit activities in the SDF Vault 4 that would cause the temperature of the saltstone in Cells $\mathrm{C}, \mathrm{G}$, and I to exceed $55^{\circ} \mathrm{C}$. ${ }^{11}$

The Savannah River National Laboratory (SRNL) was requested to verify that saltstone prepared with salt slurrys containing tetraphenylborate (TPB) remains nonhazardous (i.e., passes a TCLP for benzene) at extended curing times and over a range temperatures $\left(55\right.$ to $\left.95{ }^{\circ} \mathrm{C}\right) .{ }^{12}$ SRNL evaluated both nonradioactive (prepared with simulated Tank $48 \mathrm{H}$ waste) and radioactive (prepared with actual Tank $48 \mathrm{H}$ waste) saltstone samples that were fabricated for an ongoing benzene generation study. ${ }^{1}$ The benzene concentrations in the leachate from tests following the EPA TCLP Method 1311 protocol was the focus of this task. The release of toxic metals was not evaluated as a part of this task.

\footnotetext{
* SCDHEC ISWLF Permit \#025500-1603

† 40CFR 261.24 "Toxicity Characteristic"
} 


\subsection{APPROACH}

Saltstone samples fabricated as part of the "Tetraphenylborate Decomposition in Saltstone,"1 task were subjected to a modified TCLP zero-headspace extractor (ZHE) leaching method for volatile organic analytes (VOA) to evaluate benzene release. According to the EPA TCLP method, analyte concentrations may also be determined by a total analysis method. Samples tested were prepared with either Tank $48 \mathrm{H}$ simulant or actual Tank $48 \mathrm{H}$ waste. The nonradioactive saltstone samples were fabricated using a Tank $48 \mathrm{H}$ simulant blended with a Defense Waste Processing Facility (DWPF) Recycle simulant. The Tank $48 \mathrm{H}$ simulant ${ }^{13}$ is based on a sample of Tank $48 \mathrm{H}$ taken in 2003. ${ }^{14}$ The DWPF recycle simulant composition targeted the average sodium and the maximum anion and mercury content of the Tank $23 \mathrm{H}$ and Tank $24 \mathrm{H}$ samples taken 100 inches from the tank bottoms as reported by Swingle. ${ }^{15}$ The customer also requested a $2 \mathrm{mg} / \mathrm{L}$ spike of palladium into the salt solution to represent a maximum level of potential TPB decomposition catalysts. ${ }^{16}$ The radioactive saltstone samples were fabricated using a sample of Tank $48 \mathrm{H}$ received at the SRNL on March 8, 2005 ${ }^{17}$ and aggregated with the same DWPF Recycle simulant used for the simulant samples. Table 2-1 is the matrix of samples that were evaluated in this study.

Table 2-1 Saltstone Samples Evaluated

\begin{tabular}{|c|c|c|c|c|c|}
\hline $\begin{array}{c}\text { Sample } \\
\text { ID }\end{array}$ & $\begin{array}{c}\text { Simulant or } \\
\text { Actual Waste }\end{array}$ & $\begin{array}{c}\text { Monolith } \\
\text { or Crushed }\end{array}$ & $\begin{array}{c}{[\mathrm{TPB}] \text { in Salt }} \\
\text { Slurry }(\mathrm{mg} / \mathrm{L})\end{array}$ & $\begin{array}{c}\text { Cure } \\
\text { Temperature } \\
\left({ }^{\circ} \mathrm{C}\right)\end{array}$ & $\begin{array}{c}\text { Cure } \\
\text { Time } \\
(\text { days })\end{array}$ \\
\hline S-8-H-a & Simulant & Monolith & 3000 & $84^{\mathrm{a}}$ & 81 \\
\hline S-7-H-c & Simulant & Monolith & 3000 & 75 & 144 \\
\hline S-9-H-b & Simulant & Monolith & 3000 & 95 & 161 \\
\hline S-9-H-c & Simulant & Monolith & 3000 & 95 & 144 \\
\hline R-6-2-b & Actual Waste & Crushed & 3000 & 65 & $92^{\mathrm{b}}$ \\
\hline R-6-6-b & Actual Waste & Monolith & 3000 & 65 & $92^{\mathrm{b}}$ \\
\hline R-7-H-a & Actual Waste & Monolith & 3000 & 75 & 145 \\
\hline R-7-H-b & Actual Waste & Monolith & 3000 & 75 & 145 \\
\hline R-9-M-b & Actual Waste & Monolith & 1000 & $95^{\mathrm{c}}$ & 148 \\
\hline R-9-H-c & Actual Waste & Monolith & 3000 & $95^{\mathrm{c}}$ & 148 \\
\hline S-B-a-2 & Simulant & Monolith & 0 & 95 & 188 \\
\hline
\end{tabular}

${ }^{\text {a }}$ Sample was cured for 100 days at $55^{\circ} \mathrm{C}$ prior to curing at $84{ }^{\circ} \mathrm{C}$.

b 24 days at $65^{\circ} \mathrm{C}, 48$ days at ambient temperature, and 68 days at $65^{\circ} \mathrm{C}=92$ days @ $65^{\circ} \mathrm{C}$.

${ }^{\mathrm{c}}$ Temperature exceeded $100{ }^{\circ} \mathrm{C}$ during the first 72 hours of testing.

\subsection{The TCLP}

The EPA TCLP method prescribes preparation, extraction, handling and subsequent analysis of a sample. Solid samples such as saltstone must pass through a $9.5 \mathrm{~mm}$ standard sieve or be crushed to meet the particle size requirements. Additional sizing requirements for analysis of samples containing volatile organic analytes (VOA) include limiting both the temperature rise during size reduction and the exposure of the fractured samples to air. The extraction step for VOA consists of placing the sample in a gas-tight vessel with the appropriate extraction fluid. ${ }^{\ddagger}$ Gentle pressure is applied to force all headspace from the vessel, and the vessel is sealed. The common equipment for extraction of VOA is the zero-headspace extractor (ZHE). After sealing the vessel, the sample is rotated at approximately $30 \mathrm{rpm}$ for approximately 18 hours. To recover the resulting

\footnotetext{
For VOA, TCLP extraction fluid \#1, a buffered sodium acetate solution with a pH of $4.93 \pm 0.05$
} 
TCLP extract, the vessel is fitted with a glass fiber filter and the extract in the vessel is expressed into an evacuated vessel (e.g. a Tedlar ${ }^{\circledR}$ bag or a gas-tight syringe). The TCLP extract is stored at $<4{ }^{\circ} \mathrm{C}$ until analysis. VOA analysis is performed by SRNL-AD using a purge and trap Gas Chromatography/Mass Spectrometry (GC/MS) similar to the methods prescribed by the EPA. ${ }^{\S}$

\subsubsection{Materials}

\subsubsection{Extraction vessel}

The special extraction vessel prescribed by the EPA TCLP method for VOA is a zero-headspace extraction vessel. The ZHE is used only for the analysis of VOA and allows for liquid/solid separation while precluding the contact of the sample and extraction fluid with headspace during agitation and extract collection, Figure 2-1. The weight and complexity of the ZHE equipment, quantities of sample (25 grams), and subsequent wastes generated, dictated the need for an equivalent method to that specified by the EPA method for extraction of volatile organics. Saltstone samples prepared with simulated Tank $48 \mathrm{H}$ from Reference 1 were used to develop a method to perform TCLP testing in the SRNL shielded cells. It was demonstrated that a $50 \mathrm{~mL}$ gas-tight syringe meets both the materials of construction and performance requirements of the ZHE.

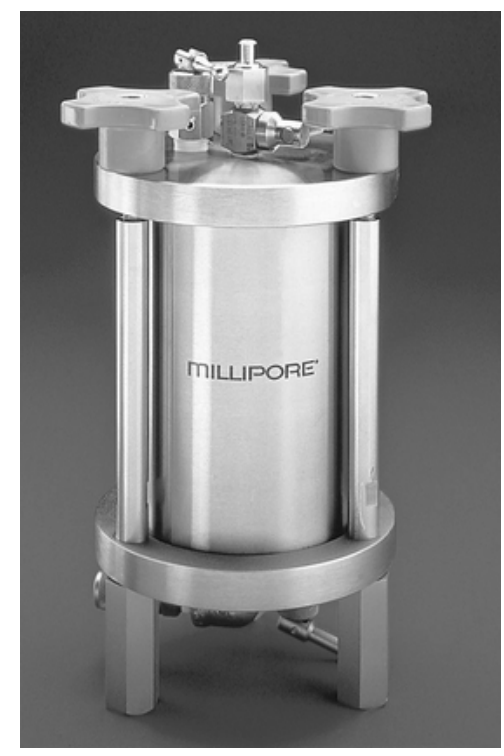

Figure 2-1 ZHE prescribed by TCLP method

\subsubsection{Agitator}

The agitation apparatus prescribed by the TCLP rotates the extraction vessel in an end-over-end fashion at $30 \pm 2 \mathrm{rpm}$. The approved rotator was deemed too large and difficult to operate in the shielded cells. A rotator modified for shielded cells operations was demonstrated to be equivalent to an approved rotator in rotational velocity and providing the end-over-end agitation specified in

\footnotetext{
$\S$ EPA Manual SW-846 Method 5030B "Purge and Trap for Aqueous Samples" and 8260B "Volatile Organic Compounds by Gas Chromatography/Mass Spectrometry (GC/MS)"
} 
the TCLP method. Figure 2-2 shows the modified rotator in service in the SRNL shielded cells with six gas-tight syringes operating as ZHE's.

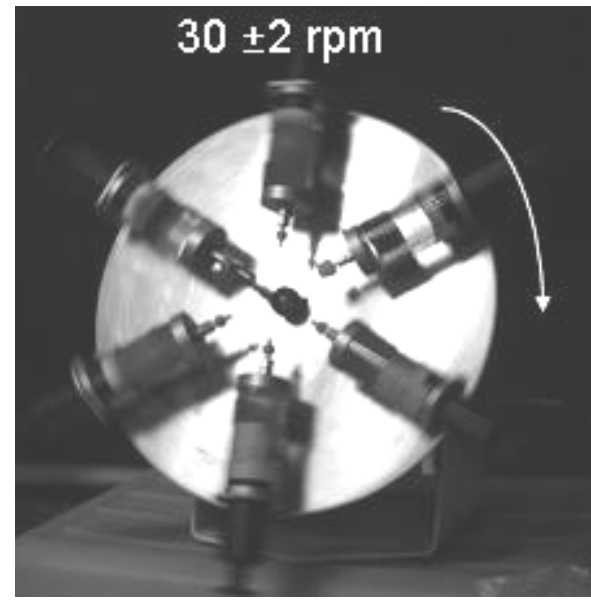

Figure 2-2 Rotator used for TCLP in SRNL shielded cells

\subsubsection{ZHE extract collector}

Gas-tight syringes are approved for collection the extract from the ZHE. For the TCLP tests performed on samples prepared with actual Tank $48 \mathrm{H}$ waste in the SRNL shielded cells, $25 \mathrm{~mL}$ gas-tight syringes were used to collect ZHE extract.

\subsubsection{Extraction fluid}

The extraction fluid prescribed by the TCLP for VOA (extraction fluid \#1) is a sodium acetate buffered acidic solution. To prepare the extraction fluid, $5.7 \mathrm{~mL}$ of glacial acetic acid was added to $500 \mathrm{~mL}$ of Type 1 ASTM water. ${ }^{* *} 64.3 \mathrm{~mL}$ of $1 \mathrm{~N} \mathrm{NaOH}$ was added and the solution was diluted to a volume of 1 liter. The $\mathrm{pH}$ of the resulting fluid was $4.97 .^{\dagger \dagger}$

\subsubsection{Sample Preparation}

The saltstone samples used for this task had already been prepared for the flammable gas generation task. ${ }^{1}$ The configuration of the samples allowed only for the loss of benzene through one end of the cylindrical sample as the bottom and the wall are encased in glass, as shown in Figure 2-3. The single exit path for benzene introduced a potential concentration gradient in the samples. To mitigate the effect of a potential benzene concentration gradient in the samples, the saltstone was quartered as shown in Figure 2-4. A jaw crusher was used to perform the size reduction to comply with the particle size requirements of the TCLP method. To evaluate the heating effect of the jaw crusher, side-by-side scoping tests were performed. Modified TCLP tests were conducted on quarters from the same sample that were either maintained at room temperature or cooled to liquid nitrogen temperatures prior to introduction into the jaw crusher. Results of the modified TCLP tests were in acceptable agreement (results for Sample S-8-H-a frozen in liquid nitrogen $(13 \cdot \mathrm{g} / \mathrm{L})$ were actually lower than without freezing $(15 \cdot \mathrm{g} / \mathrm{L})$.

\footnotetext{
** ASTM D 1193-06 Standard Specification for Reagent Water

${ }^{\dagger}$ TCLP method specifies $\mathrm{pH}$ of extraction fluid \#1 = $4.93 \pm 0.05$
} 
indicating that no measurable losses of benzene were incurred during the crushing stage and therefore cooling of the sample prior to size reduction was not necessary.

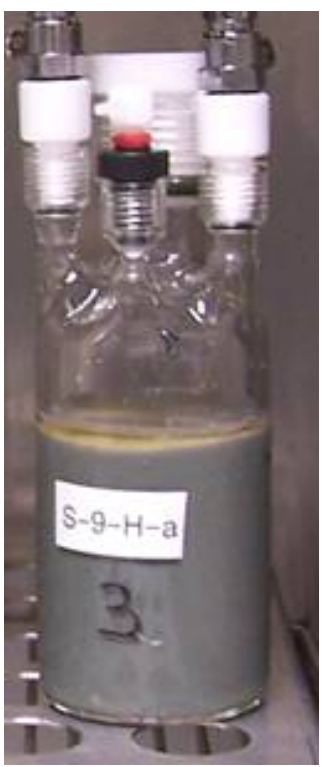

Figure 2-3. Representative sample used for study
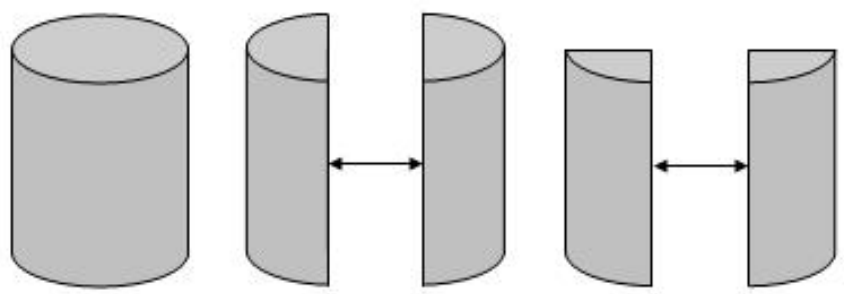

Figure 2-4 Sectioning strategy for saltstone samples

\subsubsection{Extraction}

After the saltstone was reduced to the appropriate size, the sample was weighed and placed in the ZHE. The mass of extraction fluid \#1 added was 20x the mass of the sample. The vessel was closed, inverted, and any headspace was forced from the vessel prior to sealing. The vessel was placed on the rotator and rotated at $30 \pm 2 \mathrm{rpm}$ for $18 \pm 2 \mathrm{~h}$, see Figure 2-2.

\subsubsection{Collection}

After removal from the rotator the ZHE is fitted with a glass fiber filter. The extract collector is fitted to the filter, and the filter is then saturated with extract from the ZHE. The extract from the ZHE is then filtered and collected with minimal headspace as shown in Figure 2-5. The collected extract sample is stored in a refrigerator at $4{ }^{\circ} \mathrm{C}$ until analysis. 


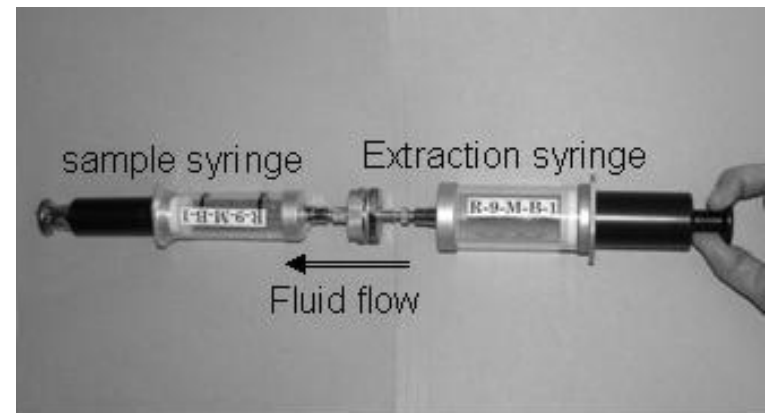

Figure 2-5 Collection of extract from gas-tight syringe ZHE

\subsection{Sample Analysis}

Sample extracts were submitted to SRNL-AD for analysis along with extracts from blanks (TCLP's performed on saltstone prepared without TPB or benzene) and a matrix spike, a blank extract spiked with a VOA standard at $0.25 \mathrm{mg}$ benzene/L extract.

GC/MS analysis was employed to identify organic compounds in the samples. Each sample was analyzed by purge and trap GC/MS. Analytical separations were carried out on a Hewlett Packard 6890 gas chromatograph, equipped with a $20 \mathrm{~m}$ DB-624 column with $0.18 \mathrm{~mm}$ diameter and 1.0 um film thickness. Quantitation was performed using a Hewlett Packard 5973 mass selective detector. The mass spectrometer tuning was confirmed within 24 hours prior to each measurement using perfluorotributylamine. 


\subsection{RESULTS}

\subsection{Nonradioactive TCLP Scoping Studies}

\subsubsection{Modified TCLP ZHE}

Initially, several modified TCLP ZHE extractions and subsequent analyses were performed on a single sample of saltstone, S-8-H-a, to determine the reproducibility of the method and dependence of benzene analysis data on sample preparation steps. Variables which were evaluated included sample temperature during size-reduction in the jaw crusher. Samples frozen in liquid nitrogen yielded similar results to those size-reduced at ambient temperature. Therefore, subsequent size-reductions of the saltstone monoliths were carried out at ambient temperature. Other variations to the modified TCLP ZHE included the size of the filter housing and the extract collector (Tedlar ${ }^{\circledR}$ Bags versus gas-tight syringes). These variations were made for ease of handling and did not represent significant deviations from the recommended specifications of the EPA method. The saltstone sample size used in the modified TCLP ZHE studies was $2 \mathrm{~g}$ for all samples tested, and TCLP extract \#1 was added at the EPA prescribed ratio of 20x the mass of the sample. Neither the sample size nor the ratio of sample to extract was evaluated as a part of this study.

Results for TCLP analyses of saltstone monolith S-8-H-a using the modified ZHE, Sample S-8$\mathrm{H}-\mathrm{a}$, and using the EPA recommended ZHE, Sample S-8-H-a-ZHE, are shown in Table 3-1. The mean values for the modified versus recommended ZHE are within the precision of GC/MS measurement $( \pm 20 \%)$ although the modified ZHE measurements are somewhat less precise (29 $\% \mathrm{RSD})$ than the EPA recommended ZHE (10\%RSD). This difference in precision may be due to the greater sample size $(25 \mathrm{~g})$ used in the EPA recommended ZHE studies. Several additional saltstone monoliths were analyzed using the modified TCLP ZHE method including samples demonstrating higher concentrations of benzene $(313 \pm 9.6 \bullet \mathrm{g} / \mathrm{L}$, for Sample S-9-H-b and $255 \pm 7$ - $\mathrm{g} / \mathrm{L}$, for Sample S-9-H-c) as well as lower concentrations of benzene $(7.9 \pm 1.9 \cdot \mathrm{g} / \mathrm{L}, \mathrm{S}-7-\mathrm{H}-\mathrm{c})$. The results for saltstone samples containing higher concentrations of benzene were more precise than those with lower concentrations. All results for the modified ZHE are comparable to the actual EPA ZHE method which reports a \% RSD range of 17-144 with a mean \% RSD of 75 for a multi-laboratory study including a variety of VOCs. ${ }^{3}$ Therefore, the modified TCLP ZHE method was deemed an appropriate method for the determination of VOCs for use in the SRNL shielded cells.

Results for all nonradioactive saltstone samples analyzed in this study were found to be below the regulatory limit of $0.5 \mathrm{mg} / \mathrm{L}(500 \cdot \mathrm{g} / \mathrm{L})$. In general, higher benzene concentrations were measured in TCLP extracts from saltstone monoliths cured at higher temperatures. For the nonradioactive samples containing TPB, the highest benzene concentration measured in TCLP extract was $313 \pm 9.6 \cdot \mathrm{g} / \mathrm{L}$ (S-9-H-b) corresponding to a concentration of $6.26 \mathrm{mg}$ of benzene $/ \mathrm{Kg}$ of saltstone. 
Table 3-1 Benzene TCLP Results for Nonradioactive Saltstone Samples

\begin{tabular}{|c|c|c|c|c|c|c|c|c|}
\hline Sample ID & ZHE & $\begin{array}{c}\text { TPB in } \\
\text { Salt } \\
\text { Solution } \\
\text { mg/L }\end{array}$ & $\begin{array}{c}\text { Curing } \\
\text { Temp } \\
\left({ }^{\circ} \mathrm{C}\right)\end{array}$ & $\begin{array}{c}\# \\
\text { of } \\
\text { TCLP } \\
\text { Rep }\end{array}$ & $\begin{array}{c}\text { Benzene } \\
\text { Result } \\
(\bullet \text { g/L })\end{array}$ & $\begin{array}{l}\text { Std } \\
\text { Dev }\end{array}$ & \% RSD & $\begin{array}{c}\text { Regulatory } \\
\text { limit } \\
(\bullet \mathrm{g} / \mathrm{L})\end{array}$ \\
\hline S-7-H-c & modified & 3000 & 75 & 2 & 7.9 & 1.9 & $24 \%$ & 500 \\
\hline S-8-H-a & modified & 3000 & 84 & 10 & 11.9 & 3.5 & $29 \%$ & 500 \\
\hline S-8-H-a-ZHE & $\mathrm{EPA}$ & 3000 & 84 & 4 & 12.5 & 1.3 & $10 \%$ & 500 \\
\hline S-9-H-b & modified & 3000 & 95 & 4 & 313 & 9.6 & $3 \%$ & 500 \\
\hline S-9-H-c & modified & 3000 & 95 & 2 & 255 & 7 & $3 \%$ & 500 \\
\hline S-B-a-2 & modified & 0 & 95 & 4 & 1.7 & 0.9 & $55 \%$ & 500 \\
\hline $\begin{array}{c}\text { Matrix spike } \\
250 \cdot \mathrm{g} / \mathrm{L}^{\#}\end{array}$ & - & & & 2 & $\begin{array}{c}245 \\
(97 \%)\end{array}$ & 7 & $3 \%$ & 500 \\
\hline $\begin{array}{c}\text { Matrix spike } \\
500 \cdot \mathrm{g} / \mathrm{L}^{\#}\end{array}$ & $\overline{--}$ & & & 2 & $\begin{array}{c}470 \\
(93 \%) \\
\end{array}$ & 28 & $6 \%$ & 500 \\
\hline
\end{tabular}

\subsubsection{Blanks and Matrix spikes}

A saltstone monolith prepared without TPB (Sample S-B-a-2) was evaluated and found to contain traces $(1.7 \cdot \mathrm{g} / \mathrm{L})$ of benzene. The source of benzene in this "blank" saltstone sample is likely the fly ash in the saltstone formulation. Matrix spikes were prepared by spiking the TCLP extract from S-B-a-2 with benzene (Table 3-1). For radioactive TCLP studies, a nonradioactive blank (S-B-a-2) and matrix spike (250 $\mathrm{g} / \mathrm{L}$ benzene in S-B-a-2 TCLP extract) were prepared and submitted concurrently for each set of modified TCLP samples prepared in the shielded cells. Blanks and spikes were prepared outside the shielded cells. 


\subsection{TCLP Studies with Radioactive Saltstone Containing Actual Tank 48H Waste}

Results for saltstone samples containing Actual Tank 48H Waste are shown in Table 3-2. Similar to the results for nonradioactive saltstone samples prepared with TPB, all results for TCLP extracts from radioactive saltstone samples prepared from Actual Tank $48 \mathrm{H}$ waste were below the regulatory limit of $0.5 \mathrm{mg} / \mathrm{L}(500 \cdot \mathrm{g} / \mathrm{L})$. The highest measured concentration of benzene in TCLP extract was $330 \cdot \mathrm{g} / \mathrm{L}$ which corresponds to a concentration of $6.60 \mathrm{mg}$ of benzene $/ \mathrm{Kg}$ of saltstone. In general the radioactive saltstone samples follow the general trend of increasing benzene concentration in TCLP extract with increasing curing temperature. However, a direct comparison of nonradioactive and radioactive samples with similar TPB concentrations and curing temperatures is not obvious. For example, radioactive samples cured at 65 and $75{ }^{\circ} \mathrm{C}$ had higher benzene concentrations than the corresponding nonradioactive samples cured at 75 and 85 ${ }^{\circ} \mathrm{C}$. On the other hand, radioactive samples cured at $95{ }^{\circ} \mathrm{C}(200 \pm 0 \cdot \mathrm{g} / \mathrm{L}, \mathrm{R}-9-\mathrm{H}-\mathrm{c})$ were somewhat lower than the corresponding simulant samples $(313 \pm 9.6 \cdot \mathrm{g} / \mathrm{L}, \mathrm{S}-9-\mathrm{H}-\mathrm{b}$ and $255 \pm 7$ - $\mathrm{g} / \mathrm{L}, \mathrm{S}-9-\mathrm{H}-\mathrm{c})$. These observations may be due in part to analytical error ( $\pm 20 \%$ GC-MS) but also due to inherent variability between the monoliths due to the distribution of TPB within the saltstone, temperature gradients in the curing oven, surface area effects, catalytic effects, and other effects beyond the scope of this study.

Based on the assumption that saltstone samples containing higher concentrations of TPB would be expected to have higher benzene concentrations, the focus of this study was saltstone samples prepared using $3000 \mathrm{mg} / \mathrm{L} \mathrm{TPB}$ in Salt Slurry with the exception of a single sample prepared with $1000 \mathrm{mg} / \mathrm{L}$ TPB. A decision to analyze R-9-M-b was a result of higher benzene evolution rates measured for this sample. ${ }^{1}$ R-9-M-b with $1000 \mathrm{mg} / \mathrm{L}$ TPB was found to have a higher concentration of benzene as analyzed by modified TCLP than R-9-H-c which was cured in a similar manner but prepared with a higher concentration of TPB. Likewise, the crushed sample R-6-2-b which exhibited higher benzene release rates ${ }^{1}$ also demonstrated higher benzene concentrations than the corresponding monolith, R-6-6-b, as measured by modified TCLP than the corresponding monolith (R-6-6-b).

Table 3-2 Benzene TCLP Results for Radioactive Saltstone Samples Containing Tank 48H Waste

\begin{tabular}{|l|l|c|c|c|c|c|c|c|}
\hline Sample ID & ZHE & $\begin{array}{c}\text { TPB in } \\
\text { Salt } \\
\text { Slurry } \\
(\mathbf{m g} / \mathbf{L})\end{array}$ & $\begin{array}{c}\text { Curing } \\
\text { Temp } \\
\left({ }^{\circ} \mathbf{C}\right)\end{array}$ & $\begin{array}{c}\# \\
\text { of } \\
\text { TCLP } \\
\text { Rep }\end{array}$ & $\begin{array}{c}\text { Benzene } \\
\text { Result } \\
(\bullet \mathbf{g} / \mathbf{L})\end{array}$ & $\begin{array}{c}\text { Std } \\
\text { Dev }\end{array}$ & $\begin{array}{c}\text { \% } \\
\text { RSD }\end{array}$ & $\begin{array}{c}\text { Regulatory } \\
\text { limit }(\bullet \mathbf{g} / \mathbf{L})\end{array}$ \\
\hline R-6-2-b & modified & 3000 & 65 & 2 & 86 & 48 & 56 & 500 \\
\hline R-6-6-b & modified & 3000 & 65 & 2 & 56 & 8 & 14 & 500 \\
\hline R-7-H-a & modified & 3000 & 75 & 2 & 100 & 0 & 0 & 500 \\
\hline R-7-H-b & modified & 3000 & 75 & 2 & 190 & 14 & 7 & 500 \\
\hline R-9-M-b & modified & 1000 & 95 & 1 & 330 & -- & -- & 500 \\
\hline R-9-H-c & modified & 3000 & 95 & 2 & 200 & 0 & 0 & 500 \\
\hline
\end{tabular}




\section{CONCLUSIONS}

Prior to deployment and testing with saltstone containing Tank $48 \mathrm{H}$ waste in the SRNL shielded cells, a modified TCLP with a ZHE was developed. The modified method was evaluated versus TCLP with an EPA recommended ZHE for the determination of benzene and verified to be an acceptable method.

TCLP results for benzene for all of the saltstone containing TPB analyzed in this study were below the regulatory limit of $0.5 \mathrm{mg} / \mathrm{L}(500 \cdot \mathrm{g} / \mathrm{L})$. These samples, ranging in benzene concentration in TCLP extract from 7.9 to $330 \cdot \mathrm{g} / \mathrm{L}$ (including both saltstone prepared using simulant containing TPB as well as actual Tank $48 \mathrm{H}$ waste), represent a range of elevated saltstone curing temperatures ( 65 to $95{ }^{\circ} \mathrm{C}$ ) and extended curing times (81 to 161 days). In general, higher curing temperatures corresponded to higher concentrations of benzene in TCLP extract.

These simulated saltstone curing conditions likely do not accurately represent all aspects of the actual temperature profile experienced by saltstone in the vault. The model offered in the work that provided the saltstone samples for this study ${ }^{1}$ linked the decomposition of TPB to both the curing temperature and the initial quantities of TPB in the saltstone. The TCLP performed on the simulant samples cured under the most extreme conditions $(3000 \mathrm{mg} / \mathrm{L}$ TPB in salt and cured at $95{ }^{\circ} \mathrm{C}$ for at least 144 days) resulted in benzene values that were greater than half the regulatory limit. The combination of 1) saltstone sample curing profiles not representative of the actual vault, 2) TCLP results for benzene on the same order of magnitude as the regulatory limit, and 3) the multi-laboratory precision in the EPA method for benzene is $44-76 \%{ }^{3}$ (depending on the sample type) indicates that a TCLP performed on a process sample prepared with salt solution $3000 \mathrm{mg} / \mathrm{L}$ TPB and cured at $95{ }^{\circ} \mathrm{C}$ may exceed the regulatory limit for benzene. The data suggests that temperature has a greater effect than the TPB concentration on the TCLP results for benzene. Therefore it is recommended that to increase confidence in TCLP results for benzene, the maximum curing temperature of saltstone be less than $95^{\circ} \mathrm{C}$. 


\section{REFERENCES}

1 Cozzi, A. D. Eibling, R. E., Marinik, A. R. and Zamecnik, J. R. Tetraphenylborate Decomposition in Saltstone - Final Report, Technical Report WSRC-STI-2006-00026 Savannah River Site, Aiken, SC 29808, 2006.

2 Code of Federal Regulations Part 40 - Protection of the Environment, Part 261-Identification and Listing of Hazardous Waste, Subpart C-Characteristics of Hazardous Waste.

3 Office of Solid Waste, US EPA. Test Methods for Evaluating Solid Waste; Physical/Chemical Methods, Third Edition; EPA 530/SW-846, Method 1311 Toxicity Characteristic Leaching Procedure; National Technical Information Service: Washington, DC, 1986.

4 Maxwell, D. Technology Development Program Plan For Tank48H Aggregation to Saltstone @ 0.2 Ci/gal Cesium. CBU-PIT-2005-00053; Savannah River Site: Aiken, SC 29808, 2005.

$5 \quad$ Poirier, M. R., Benzene TCLP Results from Saltstone Prepared with $2 X$ ITP Flowsheet Concentrations of Phenylborates (U), Technical Report WSRC-TR-99-00156, Rev 0. Savannah River Site: Aiken, SC 29808, May 21, 1999.

6 Hay, M. S., Literature Review of the Effects of Tetraphenylborate on Saltstone Grout: Benzene Evolution and TCLP Performance, Technical Report WSRC-TR-2004-00383, Rev 0 Savannah River Site, Aiken, SC 29808, November 16, 2004.

Effect of Elevated Temperatures on TPB in Saltstone Vaults. NI-SALT-04-001.

8 Langton, C.A. Direct Grout Stabilization of High Cesium Salt Waste: Salt Waste Alternative Phase III Feasibility Study; Technical Report WSRC-TR-98-00337; Savannah River Site: Aiken, SC 29808, 1998.

9 Cozzi, A.D. Formulation Development for Processing Tank 48H in Saltstone Technical Report WSRC-TR-2004-00477 Rev 0, Savannah River Site: Aiken, SC 29808, 2004.

10 Shadday, M.A. Six Cell Saltstone Pouring in Vault \#4 with a Temperature Limit of $65{ }^{\circ} \mathrm{C}$ MCLC-A-00240, Rev. 0, 2005.

11 Technical Safety Requirements, Savannah River Site, Saltstone Facility S-TSR-Z-00002 Rev 3, Savannah River Site: Aiken, SC 29808, 2005

12 A. Staub "TCLP Testing of Volatile Organics for Tank 48 Processing;" Task Technical Request SSF-TTR-2004-0008 Rev 2; Savannah River Site: Aiken, SC 29808, 2005.

13 Lambert, D.P. “Tank 48H Simulant Validation”, SRNL-LWP-2004-00009, (2004).

14 D.P. Lambert, T.B. Peters, M.E. Stallings, and S.D. Fink, Analysis of Tank 48H Samples HTF-E03-73 (June 03, 2003) and HTF-E-03-127 (September 17, 2003), WSRC-TR-2003-00720, Revision 0 (2003).

15 R.F. Swingle, Results of Analyses of Tank $23 H$ and $24 H$ Saltstone WAC Samples HTK-521HTK-528, WSRC-TR-2003-00112, (2003). 
WSRC-STI-2006-00028

Revision 0

16 A.D. Cozzi, E-mail to T.E. Chandler, 1/11/2005.

17 D.P. Lambert, "Initial Tank 48H March 05 Sample Results," SRNL-WPT-2005-00069, May 2005. Sample labeled HTF-E-05-021. 


\section{ACKNOWLEDGEMENTS}

The authors would like to thank a number of individuals for their contribution to this work: Ron Blessing (SRNL-SCO), Gary Hall (Nuclear Facility Maintenance), and Don Pak (SRNL-AD) for developing and modifying equipment necessary to perform this work in the SRNL shielded cells; Ronny Rutherford for performing the simulant tests; Phyllis Burkhalter, Monica Jenkins, Dee Wheeler, and Nan Stanley of SRNL-SCO for performing the radioactive TCLP testing; and Steve Crump, Tom White and John Young SRNL-AD for their input during experimental planning as well as sampling and analysis expertise. 
WSRC-STI-2006-00028

Revision 0

This page intentionally left blank. 


\section{Distribution:}

R. E. Edwards, Jr., SRNL

D. A. Crowley, 999-W

T. B. Calloway, 999-W

N. E. Bibler, SRNL

C.M. Jantzen, SRNL

A. D. Cozzi, 999-W

C. L. Crawford, 773-41A

K. P. Crapse, 773-43A

A. R. Jurgensen, SRNL

C. A. Langton, 773-43A

D. M. Missimer, SRNL

M. R. Poirier, 773-42A

J. R. Zamecnik, 999-W

J. R. Harbour, 773-42A

G. C. Wicks, SRNL

M. S. Miller, 704-S

J. E. Occhipinti, 704-S

A. V. Staub, 704-27S

T. E. Chandler 704-Z

J. W. Ray, 704-S

R. H. Spires, $766 \mathrm{H}$

M. A. Rios-Armstrong, 704-27S 